\title{
PERANAN KOMPUTER DALAM DUNIA PENDIDIKAN
}

\author{
Fahru Jamil \\ Visi Nusantara Maju \\ surel:fahruljamil5@gmail.com
}

\begin{abstract}
ABSTRAK
Sistem pendidikan sekolah dapat menyediakan siswa yang siap menghadapi masa depan dan lebih siap menghadapi tantangan globalisasi. Dari masa ke masa, usaha untuk menginovasi kualitas pendidikan akan terus ditingkatkan. Salah satu usaha untuk meningkatkan kulialitas pendidikan yaitu dengan memanfatkan teknologi komputer dalam pendidikan dan pembelajaran. Penggunaan komputer dalam pendidikan dan pembelajaran, harus waspada terhadap bahaya dan kesan negatif akibat penggunaan yang tidak terkontrol. Penggunaan komputer dalam pendidikan dan pembelajaran sedikit banyak sudah pasti akan mengubah corak pendidikan masa depan dan tingkah laku siswa, guru atau bahkan sistem pendidikan itu sendiri. Oleh itu, pengawalan, pengawasan dan pemanfaatan harus tetap dilakukan agar perkembangan teknologi dapat memberikan manfaat yang sebesar-besarnya bagi sektor pendidikan dan pengajaran sebagai penutup secanggih apapun peranggkat teknologi komputer tetap saja peran orang tua atau guru dalam pembelajaran masih harus lebih dominan, komputer harus diposisikan sebagai alat atau media dalam pembelajaran. Penelitian Mengetahui perkembangan teknologi di zaman sekarang, mengetahui peranan komputer pada aktivitas manusia, mengetahui dampak komputer dalam pembelajaran, engetahui pembelajaran yang menghibur dan mendidik.
\end{abstract}

\section{Kata Kunci: Peranan, Komputer pendidikan}

\section{PENDAHULUAN}

Teknologi komputer merupakan konsep yang sangat luas, kompleks dan komprehensip serta memberikan kekuatan baru dalam meningkatkan kemampuan peseta didik.Komputer suatu perkembangan teknologi yang memungkinkan untuk memperoleh informasi yang banyak dan cepat serta mudah dari berbagai belahan dunia. Karena itu diperlukan kemampuan cara mendapatkan, memilih dan mengelola produk teknologi informasi secara mudah diterapkan pada peserta didik.

Melihat substansi pembelajaran Teknologi Informasi dan Komunikasi (TIK) yang baru ditetapkan dalam kurikulum tingkat satuan pendidikan saat ini di butuhkan sarana komputer yang memadai dan bermutu. Sarana pendidikan sebagai salah satu komponen yang sangat penting dalam proses pembelajaran. Karena dengan sarana pendidikan yang lengkap dan bermutu kualitas pembelajaran akan semakin baik, dan motivasi belajar siswa akan meningkat. Hal itu 
akan berakibat meningkatnya daya serap yang pada akhirnya akan berpengaruh pada peningkatan mutu pendidikan.

\section{MOTEDE}

Metode yang digunakan adalah metode studi pustaka. Tulisan ini mengupas tentang peranan computer dalam dunia pendidikan

\section{PEMBAHASAN}

Perkembangan teknologi yang begitu pesat sangat berpengaruh terhadap dunia pendidikan. Institusi pendidikan yang tidak menerapkan teknologi khususnya komputer ini akan kalah bersaing. Penggunaan komputer pada sekolah-sekolah merupakan satu contoh sekolah untuk meningkatkan kualitas institusinya, karena dengan alat tersebut sebuah sekolah dapat meningkatkan akses, mempercepat proses dan mengurangi administrasi birokrasi konvensional. Dengan perkembangan teknologi yang begitu pesat inilah ternyata cukup mempengaruhi tatanan kehidupan manusia di semua sektor..

Revolusi teknologi membuat komputer semakin tambah pintar, kompak, dan mudah dipakai Yang tadinya berukuran besar, kini semakin mengecil. Sampai bisa dibawa ke manamana. Fungsinya pun semakin meluas seiring dengan berkembangnya temuan-temuan kreatif perangkat lunaknya. Yang semula sekadar untuk membantu memecahkan hitung-hitungan rumit kini bisa dipakai untuk olahkata, olahdata, olahgambar, dan pangkalan data berbagai bidang kehidupan. Termasuk untuk keperluan pendidikan dan hiburan bagi anak-anak. Apalagi dengan munculnya teknologi multimedia (media ganda) interaktif yang sanggup menyajikan tulisan, suara, gambar, animasi, dan video secara sekaligus maupun bergantian. Anak-anak makin akrab dengan dunia perangkat canggih yang pada awal dasawarsa '80-an' masih menjadi barang langka. Kini semakin banyak anak melek komputer.

Kemajuan teknologi komputer membuat aktivitas menjadi serba cepat serta menjadikan dunia seperti tanpa batas. Berbagai jenis informasi dapat diakses dengan cepat dan akurat. Gelombang perubahan yang mengguncangkan ini telah memaksa sektor pendidikan untuk memikirkan kembali segala sesuatu yang selama ini kita pahami tentang pembelajaran, pendidikan maupun persekolahan. Revolusi teknologi harus juga diimbangi dengan pembaharuan pendidikan, pengajaran dan persekolahan. 
Dengan masuknya teknologi informasi khususnya komputer telah banyak merubah tatanan dan peran pendidikan. Sebagai contoh, dahulunya guru merupakan sumber informasi yang utama bagi siswa dengan hadirnya komputer melalui jaringan internet telah membuat guru bukanlah satu-satunya sumber informasi, tapi infomasi dapat diakses dari komputer melalui jaringan internetnya, proses belajar mengajar yang disampaikan secara klasikal dengan metode ceramah yang membosankan. Tapi dengan hadirnya teknologi komputer menyebabkan pembelajaran dapat dilakukan secara individual dan menyenangkan. Masih banyak lagi hal yang mengalami perubahan mendasar dengan hadirnya teknologi komputer ini.

Peranan teknologi komputer pada aktivitas manusia pada saat ini memang begitu besar. Komputer telah menjadi fasilitator utama bagi kegiatan-kegiatan disemua sektor kehidupan termasuk dalam sektor pendidikan. Komputer telah memberikan andil besar terhadap perubahanperubahan yang mendasar pada struktur, operasi, dan manajemen sistem pendidikan dan pembelajaran. Berkat teknologi komputer ini berbagai kemudahan dapat dirasakan dalam proses pembelajaran seperti persentasi mengajar, akses informasi (e-learning) dan pembuatan pembelajaran berbasis komputer. Secara garis besar peranan teknologi komputer seperti,

1. Menggantikan peran manusia. Dalam hal ini, teknologi komputer melakukan otomatis terhadap suatu tugas atau proses.

2. Teknologi komputer memperkuat peran manusia, yakni dengan menyajikan infomasi terhadap suatu tugas atau proses.

3. Teknologi berperan dalam restrukturisasi terhadap peran manusia. Dalam hal ini, teknologi berperan dalam melakukan perubahan-perubahan terhadap sekumpulan tugas atau proses.

Namun bersamaan dengan itu, pemakaian komputer ini juga menyimpan dampak positif maupun dampak negatif. Di sektor pendidikan dan pembelajaran, dengan hadirnya komputer di meja belajar anak dapat menjadikan minat belajar anak menurun jika anak ini tidak ada kontrol atau dibiarkan saja anak bisa menggunakan program komputer yang justru tidak mendidik, bahkan membuat anak malas dan kecanduan sehingga enggan belajar, sebaliknya komputer dapat juga memberikan rangsangan positif dalam meningkatkan motivasi belajar anak, tentunya ini dituntut peran guru atau orang tua dalam mengontrol anak menggunakan komputer. Tetapi tidak hanya kontrol dari guru atau orang tua saja yang dapat menjadikan anak memiliki motivasi belajar yang tinggi, dibutuhkan pula pengembanagan program-program komputer yang telah didesain khusus untuk dapat digunakan dalam pembelajaran dengan berbantuan komputer. 
Penggunaan komputer dalam pendidikan dan pembelajaran sah-sah saja. Komputer dapat dijadikan seperti kertas, pensil, buku, video dan lain sebagainya. Dalam beberapa mata pelajaran tertentu komputer dapat membantu belajar menjadi lebih efektif. Komputer dapat berperan besar dalam pembelajaran jika digunakan secara semestinya. Komputer dapat membantu pendidik dalam memudahkan pembelajaran, bahkan dapat memotivasi dan mengakselerasi belajar siswa. Tapi komputer dapat juga menjadikan pendidik seperti robot dan sangat mekanis, serta menjadikan siswa seperti makhluk asing yang kurang memiliki skill sosial. Ada beberapa faktor yang menjadikan seseorang menjadi manusia mekanis karena teknologi komputer dalam dunia pendidikan dan pembelajaran;

Komputer cenderung mengisolasi. Pembelajaran melalui perantara mesin (komputer, video, TV, disket dan sebagainya) dapat memudahkan pengetahuan kognitif bagi peserta didik. Tetapi pembelajaran melalui mesin ternyata telah mengisolasi peserta didik atau pendidik secara sosial, karena seseorang hanya beriteraksi dengan mesin yang jelas-jelas mesin tidak memiliki perasaan. Kebanyakan berinteraksi atau menggunakan peranta mesin menyebabkan menurunnya sosial skill yang dimiliki seseorang.

Penyusunan program pembelajaran berdasar teknologi cendrung masih mengangap pembelajaran bersifat verbal, linear, rasionalistis, dan hanya merupakan kerja otak.Dengan tidak mengajak orang terlibat secara fisik pembelajaran berbasis komputer hanya memanfatkan sebagaian dari kecerdasan manusia. Selanjutnya Pembelajaran dengan berbantuan komputer ini hanya cocok untuk satu gaya belajar saja, karena memang pembelajaran dengan bantuan komputer merupakan pembelajaran yang pembuatannya diprogram..

Pembelajaran dengan berbantuan komputerbiasanya diprogram tidak berdasar pada penelitian atau pengalaman lapangan, karena pembelajaran dengan bantuan komputer dirancang untuk kebutuhan media dan market. Prof. Dr. Andi Hakim Nasution, menyatakan komputer itu ibaratnya pisau, kalau anak tidak dibekali pengetahuan akan fungsi dan pemakaian yang semestinya, dikhawatirkan pisau itu malah akan melukainya. Orangtua pun perlu memahami betul fungsi dan dampaknya agar anak memperoleh manfaat sebesar-besarnya dan kerugian yang sekecil-kecilnya. Masuknya komputer dalam proses belajar, menurut Andi Hakim, melahirkan suasana yang menyenangkan karena peserta didik dapat mengendalikan kecepatan belajar sesuai dengan kemampuannya. Lalu gambar dan suara yang muncul membuat anak tidak cepat bosan, sebaliknya justru merangsang untuk mengetahui lebih jauh lagi. 
Dengan desain program pembelajaran yang menarik diharapkan siswa menjadi tekun, sehingga diharapkan menjadi lebih unggul di bidangnya, lebih cerdas, lebih kreatif, dan lebih mampu melihat persoalan dari segi lain, kini dan masa datang. Suasana menyenangkan seperti ini jarang dinikmati anak ketika berhadapan dengan orangtua, maupun guru dalam belajar. Mengapa? Selain bisa jadi karena cara mengajarnya tidak menarik. "Dengan (program) komputer, anak merasa bebas dari amarah dan tekanan.Kalau anak berbuat salah, bahkan sampai seribu kali pun komputer tidak akan pernah marah dan melotot yang bisa meruntuhkan rasa kepercayaan dan harga diri si anak. Komputer biasanya malah memberi umpan balik sehingga anak tahu kesalahannya, dan bisa belajar dari kesalahan itu. Dengan demikian anak tidak segan mencoba-coba karena tidak takut berbuat salah.

Perangkat komputer sebenarnya netral. Artinya, munculnya pengaruh baik atau buruk akan tergantung pada si pemakai. Misalnya, akan kurang baik jika anak sering berlama-lama di depan komputer. Kalau ini yang terjadi, perkembangan gerak motorik kasar si anak, menjadi terbatas. Sebab, waktu yang seharusnya dipakai untuk melakukan kegiatan fisik lainnya, banyak dihabiskan di depan komputer.

Selain dari itu, kemampuannya bersosialisasi bisa terganggu. Akibatnya, nilai-nilai moral, kecintaan pada sesama makhluk hidup, ataupun kepedulian sosial, tak dapat dipelajari di sana. Untuk hal-hal seperti itu peran orang tua, guru atau teman sebaya sangatlah dibutuhkan agar keseimbangan kecerdasan tetap terjaga. Untuk itu perlu didesain pembelajaran berbantuan komputer yang melibatkan juga interaksi sosial.

1. Ada beberapa cara untuk memanfaatkan komputer sebagai pembelajaran efektif. Komputer dapat memberi hasil yang maksimal jika didesain dengan menciptakan lingkungan belajar yang dirancang dengan;

2. Kolaboratif, pembelajaran yang bersifat sosial. Hal ini dapat dilakukan dengan menciptakan pembelajaran untuk dua orang atau lebih.

3. Bermain sambil belajar. Bermain dengan iseng-iseng merupakan cara terbaik untuk memulai belajar

4. Menyediakan banyak pilihan. Gaya belajar yang didesain melalui program komputer menyediakan banyak pilihan seperti pemilihan warna, materi, pemberian suara dengan menggabungkan berbagai unsur sehingga didapat berbagai gaya belajar. 
5. Pembuatan program pembelajaran harus berdasarkan hasil pengalaman nyata atau berdasrkan hasil penelitian.

Dari berbagai cara memanfaatkan komputer untuk pembelajaran tersebut diatas, tetap saja komputer harus kita posisikan sebagai alat atau media pembelajaran. Peran pendidik atau orang tua dalam mengontrol sekaligus melihat perkembangan belajar tetap di butuhkan.

Di samping soal hubungan antara anak dan komputer, yang perlu mendapat perhatian ialah pemilihan program atau perangkat lunak. Tetapi, di pasaran banyak dijumpai beragam program aplikasi pendidikan dan hiburan untuk anak. Sebagai gambaran, program aplikasi tersebut menurut Ir. Saiful B. Ridwan, bisa dikelompokkan dalam 4 golongan berdasarkan tujuan pembuatannya, yakni:

1. Edutainment (Pendidikan). Dirancang khusus untuk tujuan pendidikan/pengajaran yang dalam penyajiannya diramu dengan unsur-unsur entertainment (hiburan) sesuai dengan materinya. Program ini umumnya mengajarkan pengetahuan dasar seperti membaca, berhitung, sejarah, geografi, dsb. Contohnya, aplikasi berjudul "Beginning Reading" (untuk membaca); "Millies's Math House”, "Mari Belajar Plus Minus" (berhitung); "Where in the World is Carmen Sandiego" (geografi); atau “The Cregon Trail” (sejarah).

2. Games (Permainan). Dirancang untuk tujuan permainan dan tidak secara khusus diberi muatan yang mengandung aspek pedagogi tertentu. Kalaupun ada tambahan pengetahuan yang didapat biasanya itu sebagai efek sampingan saja. Game ini biasanya yang paling banyak diminati oleh anak-anak maupun orang dewasa. Aplikasi games masih dikelompokkan lagi ke dalam jenis adventures (petualangan untuk mencapai tujuan tertentu dengan berbagai tantangan), arcade (permainan menghadapi objek yang bergerak cepat, "membahayakan", atau "menyerang" pemain), role play (seperti adventures tapi pemain ikut jadi salah satu tokohnya), simulation (permainan simulasi tanpa tujuan tertentu dan apa yang ingin dilakukan diserahkan kepada pemain), dan strategy (permainan seperti simulasi dengan tujuan jelas sehingga membutuhkan strategi si pemain).

3. Infotainment (Informasi). Sementara itu infotainment, dirancang untuk keperluan referensi atau penyampaian informasi lengkap tentang suatu topik tertentu. Contohnya, "Grolier Multimedia Encyclopedia” dan "Encrata '95“. 
4. Interactive Movie (Hiburan), Sedangkan interactive movie dirancang memang untuk tujuan hiburan. Program interactive movie hanya didesain untuk hiburan dan kurang memiliki nilai pendidikan (edukasi).

Dari beberapa jenis program aplikasi komputer diharapkan guru atau orang tua dapat memilih program komputer yang sesuai untuk siswa yang dapat di gunakan dalam pembelajaran. Tidak semua program aplikasi komputer mengandung unsur pendidikan dan hiburan yang sehat. Harus dipilih lagi aplikasi yang tepat untuk pembelajaran, terutama kalau ingin memilih jenis games.Tak jarang games lebih menonjolkan unsur-unsur seperti kekerasan dan agresivitas yang dapat mengarah pada perilaku sadistis. Permainan yang menyuguhkan perkelahian dua jagoan yang berakhir dengan dipenggalnya kepala atau dikoyaknya jantung lawan. Jika dibiarkan terus memainkan games sejenis itu, anak bisa terbawa pengaruh buruknya yang bersifat destruktif. Karena itu hendaknya diperhatikan betul karakter aktornya maupun cara yang dipakai aktor untuk mencapai tujuan.

Tujuan pembelajaran yang diharapkan sebenarnya "just for fun", games sangat potensial untuk dijadikan media pengajaran yang seperti itu untuk anak. Lewat permainan simulasi atau petualangan anak leluasa mengembangkan imajinasi untuk menentukan tujuannya sendiri.

Jenis edutainment atau courseware yang baik, bersifat individual. Artinya, anak bisa mengatur kecepatan belajarnya sesuai dengan kemampuan, tingkat kesulitan materi yang dipelajari, isi, strategi belajar yang akan dipakai, maupun bentuk penyajian materi. motivasi anak bisa ditingkatkan lebih lanjut karena anak merasa tertampung atau sesuai (dengan irama permainan itu). Sri Hartati (2003).

Program yang mengajarkan konsep atau proses abstrak akan sangat mendukung proses belajar-mengajar. Misalnya tentang proses terjadinya hujan, menjadi lebih kongkret daripada yang dipelajari dari buku atau diajarkan guru di kelas. Lewat program ini anak bahkan bisa mengatur jumlah awan, kelembapan udara, arah angin dan sebagainya, sehingga bisa diketahui hujan akan jatuh di mana. Program aplikasi ensiklopedia seperti misalnya "Grolier Multimedia Encyclopedia" akan memperluas wawasan pengetahuan tentang banyak hal yang telah atau belum diajarkan di sekolah. Program ensiklopedia ini disusun dengan konsep hypermedia, teks disusun per topik. Misalnya, anak ingin mengetahui tentang jalak Bali. Ketika sudah ditemukan habitatnya di Bali, ia dapat langsung mencari topik lain tentang Bali, misalnya letak geografi, budaya, penduduknya, dan sebagainya. 
Ciri program komputer pembelajaran yang baik yaitu meningkatkan kemampuan anak belajar mandiri dan memecahkan masalah. Dalam program seperti ini anak "dipaksa" menentukan sendiri apa yang hendak dilakukan. Secara tidak langsung anak diajari menganalisis, melihat permasalahan dan alternatif yang merupakan langkah pemecahan masalah. Karena ada masalah, dia harus ambil tindakan. Dengan begitu kemampuan memecahkan masalah meningkat.

\section{PENUTUP}

Sistem pendidikan sekolah dapat menyediakan siswa yang siap menghadapi masa depan dan lebih siap menghadapi tantangan globalisasi. Dari masa ke masa, usaha untuk menginovasi kualitas pendidikan akan terus ditingkatkan. Salah satu usaha untuk meningkatkan kulialitas pendidikan yaitu dengan memanfatkan teknologi komputer dalam pendidikan dan pembelajaran. Penggunaan komputer dalam pendidikan dan pembelajaran, harus waspada terhadap bahaya dan kesan negatif akibat penggunaan yang tidak terkontrol. Penggunaan komputer dalam pendidikan dan pembelajaran sedikit banyak sudah pasti akan mengubah corak pendidikan masa depan dan tingkah laku siswa, guru atau bahkan sistem pendidikan itu sendiri. Oleh itu, pengawalan,

pengawasan dan pemanfaatan harus tetap dilakukan agar perkembangan teknologi dapat memberikan manfaat yang sebesar-besarnya bagi sektor pendidikan dan pengajaran sebagai penutup secanggih apapun peranggkat teknologi komputer tetap saja peran orang tua atau guru dalam pembelajaran masih harus lebih dominan, komputer harus diposisikan sebagai alat atau media dalam pembelajaran.

\section{DAFTAR PUSTAKA}

Dryden, Gordon, Jennette Vos, 2001. Revolusi cara belajar (the learning revulation) belajar akan efektif jika dalam keadaan 'fan'.Bandung: Kaifa

De Porter Bobbi \& Hernachi Mike, (2002) Quantum Learning (membiasakan belajar nyaman dan menyenangkan), Bandung. Kaifa

Ismaniati Ch. (2001). Pengembangan program pembelajaran berbantuan komputer, Yogyakarta. FIP UNY

Meier Dave, 2002. Accelerated learning, Bandung; Kaifa

Kadir Abdul, 2002. Pengenalan Sistem Informasi, Yogyakarta. Andi Offset

Normunyati Bin Hayim, Makalah Pengajaran dan pembelajaran dengan berbantuan komputer, Malaysia 
Sadiman Arif S, dkk (1984). Media Pendidikan, pengertian, pengembangan dan pemanfaatan, Jakarta. Pustekom.

Sulfemi, Wahyu Bagja. (2009). Modul Pembelajaran Pendidikan Pancasila dan Kewarganegaraan. Bogor : STKIP Muhammadiyah Bogor.

Sulfemi, W. B. (2015). Pengaruh Metode Pembelajaran Kontekstual dan Penggunaan Media Video Pendidikan Terhadap Hasil Belajar IPS. Edutecno. 13 (2), 1, 10 .

Widaryanto dan Sulfemi, Wahyu Bagja. (2016). Korelasi Penguasaan TIK Guru Dengan Kemampuan TIK Peserta Didik. Edutecno, 14 (1), 1-10.

Sulfemi, Wahyu Bagja dan Nurhasanah. (2018). Penggunaan Metode Demontrasi dan Media Audio Visual Dalam Meningkatkan Hasil Belajar Peserta Didik Mata Pelajaran IPS. Jurnal Pendas Mahakam. 3 (2). 151-158. Sulfemi, Wahyu Bagja dan Setianingsih. (2018), Penggunaan Tames Games Tournament (TGT) Dengan Media Kartu Dalam Meningkatkan Hasil Belajar. Journal of Komodo Science Education (JKSE. 1 (1), 1 14.

Sulfemi, Wahyu Bagja dan Desmiati, Zulaicha. (2018). Model Pembelajaran Missouri Mathematics Project Berbantu Media Relief Experience dalam Meningkatkan Hasil Belajar Siswa. Jurnal Pendas Mahakam . 3 (3), 232-245.

Sulfemi, Wahyu Bagja. (2018). Modul Manajemen Pendidikan Non Formal. Bogor: STKIP Muhammadiyah Bogor.

Sulfemi, Wahyu Bagja dan Mayasari, Nova. (2019). Peranan Model Pembelajaran Value Clarification Technique Berbantuan Media Audio Visual Untuk Meningkatkan Hasil Belajar IPS. Jurnal Pendidikan. 20. (1). 53-68.

Sulfemi, Wahyu Bagja. (2019). Model Pembelajaran Kooperatif Mind Mapping Berbantu Audio Visual Dalam Meningkatkan Minat, Motivasi dan Hasil Belajar IPS. Jurnal Pendidikan Ilmu Pengetahuan Sosial Indonesia (PIPSI). 4 (1), 13 - 19. 